\title{
Antihypertensive drugs and risk of incident gout among patients with hypertension: population based case-control study
}

\author{
OPEN ACCESS
}

\author{
Hyon K Choi professor of medicine ${ }^{1}$, Lucia Cea Soriano epidemiologist ${ }^{2}$, Yuqing Zhang professor \\ of medicine ${ }^{1}$, Luis A García Rodríguez director ${ }^{2}$
}

${ }^{1}$ Section of Rheumatology and the Clinical Epidemiology Unit, Boston University School of Medicine, 650 Albany Street, Boston, MA 02118, USA; ${ }^{2}$ Spanish Centre for Pharmacoepidemiological Research (CEIFE), Madrid, Spain

\begin{abstract}
Objective To determine the independent associations of antihypertensive drugs with the risk of incident gout among people with hypertension.

Design Nested case-control study.

Setting UK general practice database, 2000-7

Participants All incident cases of gout $(n=24768)$ among adults aged 20-79 and a random sample of 50000 matched controls.

Main outcome measure Relative risk of incident gout associated with use of antihypertensive drugs.

Results After adjusting for age, sex, body mass index, visits to the general practitioner, alcohol intake, and pertinent drugs and comorbidities, the multivariate relative risks of incident gout associated with current use of antihypertensive drugs among those with hypertension ( $n=29138$ ) were 0.87 (95\% confidence interval 0.82 to 0.93 ) for calcium channel blockers, 0.81 (0.70 to 0.94$)$ for losartan, 2.36 (2.21 to 2.52 ) for diuretics, 1.48 (1.40 to 1.57) for $\beta$ blockers, 1.24 (1.17 to 1.32) for angiotensin converting enzyme inhibitors, and 1.29 (1.16 to 1.43) for non-losartan angiotensin II receptor blockers. Similar results were obtained among those without hypertension. The multivariate relative risks for the duration of use of calcium channel blockers among those with hypertension were 1.02 for less than one year, 0.88 for 1-1.9 years, and 0.75 for two or more years and for use of losartan they were 0.98 , 0.87 , and 0.71 , respectively (both $\mathrm{P}<0.05$ for trend).

Conclusions Compatible with their urate lowering properties, calcium channel blockers and losartan are associated with a lower risk of incident gout among people with hypertension. By contrast, diuretics, $\beta$ blockers, angiotensin converting enzyme inhibitors, and non-losartan angiotensin II receptor blockers are associated with an increased risk of gout.
\end{abstract}

\section{Introduction}

Hypertension is one of the most common comorbidities of gout. According to the latest estimates from the US National Health and Nutrition Examination Survey (2007-8), 74\% of patients with gout have hypertension, ${ }^{1}$ which corresponds to 6.1 million adults in the United States alone. This substantial burden of comorbidity possibly stems from copathogenesis of the two conditions or renal changes in hypertension leading to decreased urate excretion. Studies have shown that the presence of hypertension is independently associated with the risk of incident gout ${ }^{2}$ through reduced renal blood flow with increased renal and systemic vascular resistance and decreased renal excretion of urate..$^{3-6}$

Certain antihypertensive drugs also increase the levels of serum uric acid and thus may contribute to the risk of gout. For example, in addition to the well known entities of diuretic induced hyperuricaemia and gout, ${ }^{378}$ the use of $\beta$ blockers has been shown to increase levels of serum uric acid in short-term trials. ${ }^{8}$ However, calcium channel blockers and losartan have been found to lower serum uric acid levels, ${ }^{10-16}$ carrying the potential to lower the risk of gout. To date, however, no study has investigated the relation between various antihypertensive agents and the risk of gout. To address these issues, we analysed a cohort of 24768 people with newly diagnosed gout and 50 000 matched controls from the health improvement network database.

\section{Methods}

\section{Study population}

The health improvement network database contains computerised medical records entered by general practitioners in the United Kingdom. ${ }^{17}$ Data on about four million patients are systematically recorded and sent anonymously to the database. Patients included in the database are representative of the UK population for age, sex, and geographical region. ${ }^{17}$ The health improvement network collects and organises this information for the purpose of research projects. The 
computerised information includes personal characteristics of the patients, details of visits to general practitioners, diagnoses from referrals to specialists and hospital admissions, results of laboratory tests, and a free text section (information available on request). Diagnoses are recorded using READ codes. ${ }^{18} 19$ Prescriptions issued by primary care providers are recorded automatically in the database; drugs are coded using the Multilex classification (www.firstdatabank.co.uk/8/multilex-drug-datafile). An additional requirement for participating practices is to record the indication for new courses of treatment. The validity of the database for pharmacoepidemiological research has been shown. $^{20}$

We carried out a nested case-control study using data from the health improvement network database between January 2000 and December 2007. The source population included all adults aged 20-89 with permanent registration status or who had died in the last update of the database. Study cohort members were required to have been enrolled with their general practitioner for two or more years, had at least one visit to their general practitioner, and had at least one prescription in the two years before entering the study. The start date corresponded to the date when all of these eligibility criteria had been met. People had to be free of gout and cancer before entering the study. All participants in the study cohort were followed up and contributed person time from their respective start date until the earliest of one of the following end points: detection of gout, 90th birthday, death, or end of study period, whichever came first. The final cohort encompassed 1775505 people followed for an average of 5.2 years.

\section{Ascertainment of gout}

From an automatic search using READ codes we identified all people with a first ever diagnosis of gout recorded by a general practitioner. The date of gout onset (index date) was defined as the date of either the first diagnosis of gout or the first anti-gout treatment (allopurinol, colchicine, or uricosuric drugs), whichever came first, among those with a diagnosis of gout. We considered incident cases as those who had an index date (gout onset) occurring after the date of entry to the study cohort $(n=24768)$.

To evaluate the robustness of gout ascertainment, we carried out a sensitivity analysis restricting people with gout to those receiving anti-gout treatment. To this end we used the following operational definition: identified within 90 days of a first ever diagnosis of gout (index date), any anti-gout treatment (colchicine, probenecid, or uricosuric drugs), or a prescription of a non-steroidal anti-inflammatory drug on the same index date. A similar case definition of gout has been shown to have a validity of $90 \%$ in the general practice research database. ${ }^{212}$

\section{Control sampling}

From the same study cohort where we ascertained gout cases we sampled 50000 controls that were frequency matched on age, sex, and calendar year. We applied the same exclusion criteria to controls as to cases. This was done by generating at random a date encompassed within the study period for each member of the study population. If the random date for a study member was included in his or her eligible person time (follow-up period), we chose that person as an eligible control and we used the random date as their index date.

\section{Use of antihypertensive drugs}

We evaluated the potential impact of antihypertensive drugs by class: diuretics, $\beta$ blockers, calcium channel blockers, angiotensin converting enzyme inhibitors, losartan, and non-losartan angiotensin II receptor blockers. Since previous literature has suggested that, unlike other angiotensin II receptor blockers, losartan shows urate lowering properties, ${ }^{12}{ }^{13}$ we evaluated its individual effect separately from other angiotensin II receptor blockers. We classified use of antihypertensive drugs into four mutually exclusive usage groups: current use (the supply of the most recent prescription lasted until the index date or ended in the 30 days before that date), recent use (the supply of the most recent prescription ended between 31 and 365 days before the index date), past use (the supply of the most recent prescription ended more than 365 days before the index date), and never use (no recorded use at any time before the index date). Duration of treatment was calculated among current users of drugs, which we computed by summing the time of consecutive prescriptions (allowing for an maximum interval of 60 days between the end of one prescription and the start of another). To analyse potential dose effects we used information on dose from the British National Formulary (http://bnf.org/ bnf/index.htm) and classified dose of antihypertensive drug into three groups: medium or low (recommended starting doses or lower), high (higher than recommended starting doses), and unknown.

\section{Covariate assessment}

From the database we collected data on personal characteristics and lifestyle factors such as alcohol use, smoking, and body mass index, as well as comorbidities such as ischaemic heart disease, hypertension, hyperlipidaemia, renal failure, and heart failure before the index date. The presence of these comorbidities was defined using READ codes for diagnosis as recorded by the general practitioners. We also ascertained the numbers of visits to a general practitioner, referrals, and admission to hospital in the year before the index date.

\section{Statistical analysis}

Using unconditional logistic regression we estimated the odds ratios and 95\% confidence intervals for gout associated with use of calcium channel blockers, losartan, and other antihypertensive drug classes. Our multivariate analyses were adjusted for the frequency matched variables, visits to a general practitioner, and the covariates of body mass index (five categories), alcohol use (six categories), smoking (four categories), ischaemic heart disease, hypertension, hyperlipidaemia, and renal failure. To estimate the independent impact of each drug class, even among those who used a combination of antihypertensive drug classes, we simultaneously adjusted these regression models for each antihypertensive drug class. In addition we examined associations with relatively common combinations of antihypertensive treatment in our study population ( $>3 \%$ prevalence of use among users of antihypertensives) compared with no antihypertensive use while adjusting for other combinations and the same set of covariates. Under our study design the odds ratio is an unbiased estimator of the incidence rate ratio and we have reported odds ratio estimates as relative risks throughout this paper. We calculated absolute risk differences by applying these relative risks to the incidence rates of gout derived from our underlying cohort. We carried out stratified analyses by presence of hypertension to explore potential differences in the impact of antihypertensive drugs depending on the presence of hypertension and to help isolate the impact of particular antihypertensives. We tested the significance of the interaction with a likelihood ratio test by introducing the interaction term to our final model with the main terms. 


\section{Results}

The study included 24768 patients with newly diagnosed gout and 50000 controls; table $1 \Downarrow$ shows their characteristics, stratified by the presence of hypertension. In both groups gout was associated with an increased number of visits to a general practitioner, alcohol use, adiposity, ischaemic heart disease, hyperlipidaemia, and renal failure. In total, 12858 (51.9\%) patients with gout had a recorded diagnosis of hypertension before the diagnosis of gout. After adjusting for age, sex, calendar year, and visits to a general practitioner, the relative risk for incident gout among those with hypertension was 1.99 (95\% confidence interval 1.92 to 2.06 ) compared with those without hypertension. After further adjustment for other covariates, this relative risk was attenuated but remained significant $(1.75,1.69$ to 1.82$)$.

Compared with no use of calcium channel blockers, current use among people with hypertension was associated with a lower risk of developing gout (table $2 \Downarrow$ ). After adjusting for age, sex, calendar year, and visits to a general practitioner, the relative risk for gout among those currently using calcium channel blockers was 0.95 (0.90 to 1.00). After adjusting for other covariates and other antihypertensive drugs, the multivariate relative risk was 0.87 ( 0.82 to 0.93 ). (The corresponding absolute risk difference was 60 cases per 100000 person years.) The multivariate relative risks for individual calcium channel blockers were 0.79 ( 0.73 to 0.86 ) for amlodipine, 0.87 ( 0.78 to $0.97)$ for nifedipine, and 0.86 (0.75 to 0.99$)$ for diltiazem. The associations were similar among people without hypertension ( $\mathrm{P}=0.17$ for interaction, table 2 ). The multivariate relative risks for calcium channel blockers according to duration of use among those with hypertension were 1.04 for less than one year, 0.89 for 1-1.9 years, and 0.77 for two or more years (95\% confidence interval 0.71 to $0.83, \mathrm{P}<0.001$ for trend, table $3 \Downarrow$ ). The inverse association was stronger with high dose use of calcium channel blockers than with medium or low dose use (multivariate relative risk $0.80 v 0.90 ; \mathrm{P}=0.02$, table $4 \Downarrow$ ).

Similarly, current use of losartan among those with hypertension was associated with a lower risk of developing gout (multivariate relative risk compared with no use of losartan was $0.81,0.70$ to 0.94 , table 2). (The corresponding absolute risk difference was 86 cases per 100000 person years.) The association was not significantly different among those without hypertension ( $\mathrm{P}=0.20$ for interaction), but the frequency of losartan use in the group without hypertension was low (table 2). The multivariate relative risks according to duration of use among those with hypertension were 0.97 for less than one year, 0.86 for 1-1.9 years, and 0.70 for two or more years $(0.57$ to 0.86 , $\mathrm{P}=0.02$ for trend, table 3 ). The inverse association tended to be stronger with high dose use of losartan than with medium or low dose use (multivariate relative risk $0.66 v 0.88 ; \mathrm{P}=0.06$, table 4).

In contrast, current use of diuretics, $\beta$ blockers, angiotensin converting enzyme inhibitors, and non-losartan angiotensin II receptor blockers among those with hypertension were all associated with an increased risk of developing gout. Compared with no use of diuretics, current use was associated with the greatest multivariate relative risk $(2.36,2.21$ to 2.52$)$. The corresponding multivariate relative risks of incident gout were 1.48 (1.40 to 1.57 ) for $\beta$ blockers, 1.24 (1.17 to 1.32 ) for angiotensin converting enzyme inhibitors, and 1.29 (1.16 to 1.43) for non-losartan angiotensin II receptor blockers (table 2). (The respective absolute risk differences were 572, 218, 109, and 132 cases per 100000 person years.) These multivariate relative risks tended to increase with increasing duration of use among those with hypertension $(\mathrm{P}<0.05$ for trend) except for $\beta$ blockers and non-losartan angiotensin II receptor blockers (table 3). These associations tended to be stronger with higher doses than with medium or low doses, except for angiotensin converting enzyme inhibitors (table 4). Overall, these relative risks tended to be similar among those without hypertension except for the relation between duration of use and non-losartan angiotensin II receptor blockers. Notably, the frequency of such use in this group was low.

In our sensitivity analysis, restricting gout cases to those receiving anti-gout treatment $(n=19749)$, the multivariate relative risks of incident gout associated with current use of antihypertensive drugs among those with hypertension $(n=10$ 195) were 0.87 ( 0.82 to 0.93 ) for calcium channel blockers, 0.78 (0.67 to 0.92 ) for losartan, 2.35 (2.19 to 2.53) for diuretics, 1.49 (1.40 to 1.59) for $\beta$ blockers, 1.25 (1.17 to 1.33) for angiotensin converting enzyme inhibitors, and 1.31 (1.17 to 1.47 ) for non-losartan angiotensin II receptor blockers.

The direction and magnitude of associations with common combination therapy were consistent with those from options for monotherapy. In commonly used dual therapy options that included diuretics, the multivariate relative risks for incident gout compared with no use of antihypertensives were larger with angiotensin converting enzyme inhibitors $(3.17,2.90$ to 3.47) and with $\beta$ blockers (3.33, 3.03 to 3.66) than with calcium channel blockers (2.11, 1.87 to 2.38$)$. Similarly, in combined use of $\beta$ blockers, the corresponding relative risk with angiotensin converting enzyme inhibitors (1.70, 1.48 to 1.96$)$ tended to be larger than that with calcium channel blockers $(1.24,1.07$ to 1.96$)$, whereas the relative risk for the combination of angiotensin converting enzyme inhibitors and calcium channel blockers was not significant $(1.13,0.96$ to 1.32$)$. Similarly, in triple combination therapy options that included both diuretics and angiotensin converting enzyme inhibitors, the multivariate relative risks for incident gout were larger with $\beta$ blockers $(3.88$, 3.43 to 4.38$)$ than with calcium channel blockers $(2.30,2.01$ to 2.63). Notably, the multivariate relative risk for the combined use of calcium channel blockers and losartan was $0.66(0.39$ to $1.13)$, but the frequency of combined use was low $(<1 \%)$.

\section{Discussion}

In this large general practice cohort representative of the UK population, we found that use of calcium channel blockers and losartan was associated with a moderately lower risk of incident gout among patients with hypertension. These associations were independent of use of other evaluated antihypertensive drugs and other risk factors for gout such as age, body mass index, smoking, alcohol use, and presence of ischaemic heart disease, hyperlipidaemia, hypertension, and renal failure. These inverse associations were stronger with both a longer duration and a higher dose of use. In contrast, we found that use of diuretics, $\beta$ blockers, angiotensin converting enzyme inhibitors, and non-losartan angiotensin II receptor blockers was associated with an increased risk of incident gout among patients with hypertension. The magnitude of relative risk was strong with diuretic use and more moderate with the other antihypertensive drugs. These associations were also independent of use of other antihypertensives and other risk factors for gout and tended to become stronger with a longer duration of use and a higher dose. The absolute risk difference was the largest with diuretic use (about six cases per 1000 person years) and more moderate with the other agents (one or two cases per 1000 person years). The current study provides the first large scale evidence for the 
independent differential effect of antihypertensive drugs for and against the risk for gout.

The inverse association between use of calcium channel blockers and risk of incident gout possibly stems from its action on renal function. An increase in uric acid excretion has been observed with calcium channel blockers. ${ }^{11-13}$ Calcium channel blockers could increase the glomerular filtration rate and consequently the clearance rates of uric acid and creatinine. For example, amlodipine has been found to increase the output of fluid from the proximal tubules, as shown by the significant decrease observed in the fractional proximal reabsorption of sodium and the corresponding increase in the reabsorption of sodium in the distal tubule ${ }^{11}$ Furthermore, nifedipine, which possesses renal vasodilatory effects, ${ }^{23}$ has been found to reduce serum uric acid levels compared with a placebo in the A Coronary Disease Trial Investigating Outcome with Nifedipine GITS (ACTION) trial $(\mathrm{n}=7665) .{ }^{10}$ Our data indicate that these amlodipine and nifedipine effects on serum uric acid levels can be translated into $21 \%$ and $13 \%$ decreased risks of gout, respectively, and a similar protective association can be expected from diltiazem as well.

Losartan reduces serum uric acid levels by $20-25 \%$ by producing a uricosuric effect in healthy volunteers, patients with hypertension, and transplant recipients. ${ }^{12} 13156^{1626}$ The uricosuric effect of losartan has been described to be similar to that observed with classic uricosuric agents such as probenecid. ${ }^{12}{ }^{13}$ However, this uricosuric mechanism does not seem to be related to angiotensin II antagonism, as other angiotensin II antagonists do not share the property. For example, other angiotensin II antagonists, including valsartan $80 \mathrm{mg}$ once daily, ${ }^{27-30}$ candesartan 8-16 mg daily, ${ }^{31}$ telmisartan ${ }^{32}$ irbesartan, ${ }^{24}{ }^{33}$ and eprosartan $600 \mathrm{mg}^{34-36}$ do not increase uricosuria and thus do not decrease serum uric acid levels. ${ }^{8}$ Similarly, angiotensin converting enzyme inhibitors have not been associated with lower serum uric levels. ${ }^{16}$ Several experiments, including a Xenopus oocyte model of urate transport injected with URAT1-encoding RNA, ${ }^{37}$ have indicated that losartan can directly inhibit URAT1 from the apical side of tubular cells through cis-inhibition as with other uricosuric compounds such as probenecid and benzbromarone. ${ }^{3738}$ These data suggest that URAT1 could be the key action site of losartan, as with other uricosuric agents.

We found that other antihypertensive drugs were associated with an increased risk of incident gout. Diuretics increase the net reabsorption of uric acid in the proximal tubule of the nephron and thereby reduce urinary excretion and increase the risk of hyperuricaemia ${ }^{78}$ and gout. ${ }^{2}$ The increase in serum uric acid concentration and the risk of gout caused by diuretics may be noted within a few days of the start of treatment. ${ }^{39} 40$ Although not as impressive as the hyperuricaemic property of diuretics, $\beta$ blockers, including propranolol, atenolol, metoprolol, timolol, and alprenolol, also have been shown to increase serum uric acid levels. ${ }^{8}{ }^{9}$ For example, atenolol 50-100 mg daily for 12 weeks increased uric acid levels by $0.5 \mathrm{mg} / \mathrm{dL}^{41}$ and the addition of propranolol was associated with a $0.3 \mathrm{mg} / \mathrm{dL}$ increase of serum uric acid levels. ${ }^{42}$ The mechanism of these urate raising effects of $\beta$ blockers remains unknown as the data on the effects of $\beta$ blockers on renal urate excretion have been unclear. For example, whereas single doses of atenolol, propranolol, and tertatolol did not modify the renal clearance of uric acid or the 24 hour urinary excretion of uric acid in healthy people, ${ }^{42}$ propranolol was found to reduce the mean renal clearance of uric acid in patients with hypertension. ${ }^{43}$

\section{Clinical and public health implications}

Our findings may have practical implications in the management of hypertension, particularly among those who are at a higher risk of developing gout. Our data suggest that calcium channel blockers or losartan would be preferred to other antihypertensive drugs if prevention of gout is relevant and other determining factors are comparable. Furthermore, from a public health perspective, using these urate lowering antihypertensive drugs could help reduce the high comorbidity burden of gout and hypertension. ${ }^{1}$ As our findings are based on the reference point of no use of each corresponding antihypertensive drug, the difference in risk of gout between urate lowering agents (for example, losartan) compared with urate raising agents (for example, thiazide) would be even greater, which could in turn lead to noteworthy differences in risk-benefit ratios, particularly in populations at high risk for gout.

\section{Strengths and limitations of the study}

This study was carried out using a large UK general practice population; therefore, findings are likely to be applicable to the general population. As antihypertensive drugs are used for other clinical conditions, the overall consistency of the results stratified by hypertension helped to sort out potential drug effects from those of the underlying conditions. Because the definition of gout was based on doctors' diagnoses, a certain level of misclassification of use is inevitable. A diagnosis of gout could often have been recorded based on the suggestive clinical presentation of gout without documentation of monosodium urate crystals. However, any non-differential misclassification of these diagnoses would have biased the study results toward the null and would not explain the strong associations and dose-response relations observed in this study. Furthermore, when we used doctors' diagnoses of gout combined with anti-gout drug use (which showed a validity of $90 \%{ }^{21} 22$ ) as our case definition, our results remained almost identical. Despite the large size of the study cohort, the number of participants in certain subgroups (for example, use of angiotensin II receptor blockers in the group without hypertension or various combination therapy options) was relatively small, which limited our ability to obtain robust estimates. Replicating these results in the context of a larger prospective cohort would be valuable. Such a larger study context would also be useful for quantifying the effects of switching antihypertensive drugs.

\section{Conclusions}

Our findings suggest that calcium channel blockers and losartan may be protective against the risk of gout among people with hypertension. These data are compatible with previous findings that suggested these drugs have urate lowering properties. In contrast, diuretics, $\beta$ blockers, angiotensin converting enzyme inhibitors, and non-losartan angiotensin II receptor blockers are associated with an increased risk of gout. These data may have practical implications for choosing the appropriate antihypertensive drugs in patients with hypertension, a common comorbidity of gout.

Contributors: All authors conceived and designed the study and analysed the data. HKC drafted the manuscript and is guarantor. All authors helped interpret the results.

Funding: This work was supported in part by grants from the National Institutes of Health (AR056291 and P60AR047785). The Spanish Centre for Pharmacoepidemiological Research has received an unrestricted research grant from Novartis to work on other projects related to gout. 


\section{What is already known on this topic}

Hypertension is a common comorbidity of gout, affecting up to $74 \%$ of patients with gout Unlike other antihypertensives, calcium channel blockers and losartan may reduce the risk of gout by lowering urate acid levels No study has, however, investigated this potential link

\section{What this study adds}

Compatible with their urate lowering properties, calcium channel blockers and losartan are associated with a lower risk of incident gout among people with hypertension

By contrast, diuretics, $\beta$ blockers, angiotensin converting enzyme inhibitors, and non-losartan angiotensin II receptor blockers are associated with an increased risk of gout

The funding sources had no role in the design, conduct, or reporting of the study or in the decision to submit the manuscript for publication.

Competing interests: All authors have completed the ICMJE uniform disclosure form at www.icmje.org/coi_disclosure.pdf (available on request from the corresponding author) and declare that $\mathrm{HKC}$ has received research funding for other projects from Takeda Pharmaceuticals and has served on advisory boards for Takeda Pharmaceuticals, Savient Pharmaceuticals, and URL Pharma; the authors have no relationship with companies that might have an interest in the submitted work in the previous three years; they have no non-financial interests that may be relevant to the submitted work. Ethical approval: This study was approved by the National Health Service research ethics committee (09/H0305/75).

Data sharing: No additional data available.

1 Zhu Y, Pandya BJ, Choi HK. Comorbidities of gout and hyperuricemia in the US genera population-the National Health and Nutrition Examination Survey 2007-2008. Am J Med (In press).

2 Choi HK, Atkinson K, Karlson EW, Curhan G. Obesity, weight change, hypertension, diuretic use, and risk of gout in men: the health professionals follow-up study. Arch Intern Med 2005;165:742-8.

3 Choi HK, Mount DB, Reginato AM. Pathogenesis of gout. Ann Intern Med 2005;143:499-516.

Wyngaarden JB, Kelley WN. Gout and hyperuricemia. Grune \& Stratton, 1976.

5 Prebis JW, Gruskin AB, Polinsky MS, Baluarte HJ. Uric acid in childhood essentia hypertension. J Pediatr 1981;98:702-7.

6 Messerli FH, Frohlich ED, Dreslinski GR, Suarez DH, Aristimuno GG. Serum uric acid in essential hypertension: an indicator of renal vascular involvement. Ann Intern Med 1980;93:817-21.

7 Comparative effects of ticrynafen and hydrochlorothiazide in the treatment of hypertension. N Engl J Med 1979;301:293-7.

8 Reyes AJ. Cardiovascular drugs and serum uric acid. Cardiovasc Drugs Ther 2003;17:397-414.

9 Adverse reactions to bendrofluazide and propranolol for the treatment of mild hypertension. Report of Medical Research Council Working Party on Mild to Moderate Hypertension. Lancet 1981;2:539-43.

10 Ruilope LM, Kirwan BA, de Brouwer S, Danchin N, Fox KA, Wagener G, et al. Uric acid and other renal function parameters in patients with stable angina pectoris participating in the ACTION trial: impact of nifedipine GITS (gastro-intestinal therapeutic system) and relation to outcome. J Hypertens 2007;25:1711-8.

11 Chanard J, Toupance O, Lavaud S, Hurault de Ligny B, Bernaud C, Moulin B. Amlodipine reduces cyclosporin-induced hyperuricaemia in hypertensive renal transplant recipients. Nephrol Dial Transplant 2003;18:2147-53.

12 Burnier M, Waeber B, Brunner HR. Clinical pharmacology of the angiotensin II receptor antagonist losartan potassium in healthy subjects. $J$ Hypertens Suppl 1995:13:S23-8.

13 Burnier M, Roch-Ramel F, Brunner HR. Renal effects of angiotensin II receptor blockade in normotensive subjects. Kidney Int 1996;49:1787-90.

14 Shahinfar S, Simpson RL, Carides AD, Thiyagarajan B, Nakagawa Y, Umans JG, et al. Safety of losartan in hypertensive patients with thiazide-induced hyperuricemia. Kidney Int 1999;56:1879-85.

15 Hoieggen A, Alderman MH, Kjeldsen SE, Julius S, Devereux RB, De Faire U, et al. The impact of serum uric acid on cardiovascular outcomes in the LIFE study. Kidney Int 2004:65:1041-9.

16 Alderman M, Aiyer KJ. Uric acid: role in cardiovascular disease and effects of losartan. Curr Med Res Opin 2004;20:369-79.

17 Bourke A, Dattani H, Robinson M. Feasibility study and methodology to create a quality-evaluated database of primary care data. Inform Prim Care 2004:12:171-7.

18 O'Neil M, Payne C, Read J. Read codes version 3: a user led terminology. Methods Inf Med 1995;34:187-92

19 Stuart-Buttle CD, Read JD, Sanderson HF, Sutton YM. A language of health in action: Read codes, classifications and groupings. Proc AMIA Annu Fall Symp 1996:75-9.

20 Lewis JD, Schinnar R, Bilker WB, Wang X, Strom BL. Validation studies of the health improvement network (THIN) database for pharmacoepidemiology research. Pharmacoepidemiol Drug Saf 2007:16:393-401.

21 Meier $\mathrm{CR}$, Jick H. Omeprazole, other antiulcer drugs and newly diagnosed gout. Br J Clin Pharmacol 1997;44:175-8.
22 Alonso A, Rodriguez LA, Logroscino G, Hernan MA. Gout and risk of Parkinson disease: a prospective study. Neurology 2007:69:1696-700.

23 Hayashi K, Ozawa Y, Fujiwara K, Wakino S, Kumagai H, Saruta T. Role of actions of calcium antagonists on efferent arterioles-with special references to glomerular hypertension. Am J Nephrol 2003;23:229-44.

24 Wurzner G, Gerster JC, Chiolero A, Maillard M, Fallab-Stubi CL, Brunner HR, et al. Comparative effects of losartan and irbesartan on serum uric acid in hypertensive patients with hyperuricaemia and gout. $J$ Hypertens 2001;19:1855-60

25 Minghelli G, Seydoux C, Goy JJ, Burnier M. Uricosuric effect of the angiotensin II receptor antagonist losartan in heart transplant recipients. Transplantation 1998;66:268-71.

26 Hamada T, Hisatome I, Kinugasa Y, Matsubara K, Shimizu H, Tanaka H, et al. Effect of the angiotensin II receptor antagonist losartan on uric acid and oxypurine metabolism in healthy subjects. Intern Med 2002;41:793-7.

27 Elliott WJ, Calhoun DA, DeLucca PT, Gazdick LP, Kerns DE, Zeldin RK. Losartan versus valsartan in the treatment of patients with mild to moderate essential hypertension: data from a multicenter, randomized, double-blind, 12-week trial. Clin Ther 2001;23:1166-79.

28 Gonzalez-Ortiz M, Mora-Martinez JM, Martinez-Abundis E, Balcazar-Munoz BR. Effect of valsartan on renal handling of uric acid in healthy subjects. J Nephrol 2000;13:126-8.

29 Monterroso VH, Rodriguez Chavez V, Carbajal ET, Vogel DR, Aroca Martinez GJ, Garcia $\mathrm{LH}$, et al. Use of ambulatory blood pressure monitoring to compare antihypertensive efficacy and safety of two angiotensin II receptor antagonists, losartan and valsartan. Losartan Trial Investigators. Adv Ther 2000;17:117-31.

30 Muller P, Flesch G, de Gasparo M, Gasparini M, Howald H. Pharmacokinetics and pharmacodynamic effects of the angiotensin II antagonist valsartan at steady state in healthy, normotensive subjects. Eur J Clin Pharmacol 1997:52:441-9.

31 Manolis AJ, Grossman E, Jelakovic B, Jacovides A, Bernhardi DC, Cabrera WJ, et al. Effects of losartan and candesartan monotherapy and losartan/hydrochlorothiazide combination therapy in patients with mild to moderate hypertension. Losartan Trial Investigators. Clin Ther 2000;22:1186-203.

32 Burgess ED, Buckley S. Acute natriuretic effect of telmisartan in hypertensive patients. Am J Hypertens 2000;13:183A.

33 McIntyre M, MacFadyen RJ, Meredith PA, Brouard R, Reid JL. Dose-ranging study of the angiotensin II receptor antagonist irbesartan (SR 47436/BMS-186295) on blood pressure and neurohormonal effects in salt-deplete men. J Cardiovasc Pharmacol 1996;28:101-6.

34 Puig JG, Torres R, Ruilope LM. AT1 blockers and uric acid metabolism: are there relevan differences? J Hypertens Suppl 2002;20:S29-31.

35 Puig JG, Mateos F, Buno A, Ortega R, Rodriguez F, Dal-Re R. Effect of eprosartan and losartan on uric acid metabolism in patients with essential hypertension. $J$ Hypertens 1999:17:1033-9.

36 Ilson BE, Martin DE, Boike SC, Jorkasky DK. The effects of eprosartan, an angiotensin II AT1 receptor antagonist, on uric acid excretion in patients with mild to moderate essentia hypertension. J Clin Pharmacol 1998;38:437-41

37 Enomoto A, Kimura $\mathrm{H}$, Chairoungdua A, Shigeta $\mathrm{Y}$, Jutabha $\mathrm{P}$, Cha SH, et al. Molecular identification of a renal urate anion exchanger that regulates blood urate levels. Nature 2002:417:447-52.

38 Hamada T, Ichida K, Hosoyamada M, Mizuta E, Yanagihara K, Sonoyama K, et al. Uricosuric action of losartan via the inhibition of urate transporter 1 (URAT 1) in hypertensive patients. Am J Hypertens 2008;21:1157-62.

39 Leary WP, Reyes AJ, Wynne RD, van der Byl K. Renal excretory actions of furosemide, of hydrochlorothiazide and of the vasodilator flosequinan in healthy subjects. J Int Med Res 1990;18:120-41.

40 Hunter DJ, York M, Chaisson CE, Woods R, Niu J, Zhang Y. Recent diuretic use and the risk of recurrent gout attacks: the online case-crossover gout study. J Rheumatol 2006;33:1341-5

41 Andersen GS. Atenolol versus bendroflumethiazide in middle-aged and elderly hypertensives. Acta Med Scand 1985;218:165-72.

42 Pedersen OL, Jacobsen FK, Stengaard-Pedersen K. Renal uric acid handling is not affected by beta-adrenoceptor blockade in normotensive subjects. Eur J Clin Pharmacol 1985;28:223-4

43 Malini PL, Strocchi E, Cervi V, Ambrosioni E. The metabolic effects of enalapril. Clin Exp Hypertens A 1987:9:675-9.

Accepted: 4 November 2011

\section{Cite this as: BMJ 2012;344:d8190}

This is an open-access article distributed under the terms of the Creative Common Attribution Non-commercial License, which permits use, distribution, and reproduction in any medium, provided the original work is properly cited, the use is non commercial and is otherwise in compliance with the license. See: http://creativecommons.org/licenses/bync/2.0/ and http://creativecommons.org/licenses/by-nc/2.0/legalcode. 


\section{Tables}

\begin{tabular}{|c|c|c|c|c|c|c|}
\hline \multirow[b]{2}{*}{ Variables } & \multicolumn{3}{|c|}{ Hypertension } & \multicolumn{3}{|c|}{ No hypertension } \\
\hline & $\begin{array}{c}\text { No }(\%) \text { of controls } \\
\quad(n=16280)\end{array}$ & $\begin{array}{c}\text { No }(\%) \text { of cases } \\
\quad(n=12858)\end{array}$ & $\begin{array}{c}\text { Relative risk* }(95 \% \\
\text { Cl) }\end{array}$ & $\begin{array}{c}\text { No }(\%) \text { of controls } \\
\quad(n=33720)\end{array}$ & $\begin{array}{c}\text { No }(\%) \text { of cases } \\
(n=11910)\end{array}$ & $\begin{array}{c}\text { Relative risk }{ }^{*}(95 \% \\
\mathrm{Cl})\end{array}$ \\
\hline Men & $10898(66.94)$ & $8431(65.57)$ & - & $26055(77.27)$ & 9515 (79.89) & - \\
\hline Women & $5382(33.06)$ & $4427(34.43)$ & - & 7665 (22.73) & $2395(20.11)$ & - \\
\hline \multicolumn{7}{|l|}{ Age (years): } \\
\hline $20-49$ & 1012 (6.22) & 1160 (9.02) & - & $9199(27.28)$ & $4130(34.68)$ & - \\
\hline $50-59$ & 2366 (14.53) & $2202(17.13)$ & - & 7745 (22.97) & 2671 (22.43) & - \\
\hline $60-69$ & $4410(27.09)$ & $3423(26.62)$ & - & $7520(22.30)$ & $2330(19.56)$ & - \\
\hline $70-79$ & $5628(34.57)$ & $4064(31.61)$ & - & $6268(18.59)$ & $1794(15.06)$ & - \\
\hline $80-89$ & 2864 (17.59) & 2009 (15.62) & - & $2988(8.86)$ & $985(8.27)$ & - \\
\hline \multicolumn{7}{|c|}{$\begin{array}{l}\text { No of visits to } \\
\text { general practitioner: }\end{array}$} \\
\hline $0-4$ & $3743(22.99)$ & $1822(14.17)$ & 1 & 18957 (56.22) & $4963(41.67)$ & 1 \\
\hline $5-9$ & $4957(30.45)$ & 3414 (26.55) & $1.33(1.23$ to 1.43$)$ & $8244(24.45)$ & 3278 (27.52) & 1.59 (1.51 to 1.68$)$ \\
\hline $10-19$ & 5425 (33.32) & $4911(38.19)$ & 1.70 (1.58 to 1.82$)$ & $4997(14.82)$ & $2489(20.90)$ & 2.08 (1.95 to 2.21$)$ \\
\hline$\geq 20$ & $2155(13.24)$ & $2711(21.08)$ & 2.31 (2.12 to 2.51$)$ & $1522(4.51)$ & $1180(9.91)$ & 3.26 (2.99 to 3.56 ) \\
\hline \multicolumn{7}{|l|}{ Smoking: } \\
\hline Non-smoker & $8239(50.61)$ & $6074(47.24)$ & 1 & $15793(46.84)$ & $5484(46.05)$ & 1 \\
\hline Current smoker & $2500(15.36)$ & $1516(11.79)$ & 0.78 (0.73 to 0.84$)$ & $7431(22.04)$ & 2266 (19.03) & 0.82 (0.77 to 0.87$)$ \\
\hline Former smoker & $4879(29.97)$ & $4901(38.12)$ & 1.16 (1.10 to 1.22$)$ & $6000(17.79)$ & $3050(25.61)$ & $1.24(1.17$ to 1.31$)$ \\
\hline Unknown & $662(4.07)$ & $367(2.85)$ & 1.06 (0.92 to 1.22$)$ & 4496 (13.33) & 1110 (9.32) & 0.90 (0.83 to 0.97$)$ \\
\hline \multicolumn{7}{|l|}{$\begin{array}{l}\text { Alcohol intake } \\
\text { (units/wk)t: }\end{array}$} \\
\hline Non-use & $6457(39.66)$ & $4593(35.72)$ & 1 & $9939(29.48)$ & $3035(25.48)$ & 1 \\
\hline $1-9$ & $4612(28.33)$ & 3371 (26.22) & 1.09 (1.02 to 1.15$)$ & $8750(25.95)$ & $2589(21.74)$ & 0.99 (0.94 to 1.06$)$ \\
\hline $10-24$ & $2593(15.93)$ & 2544 (19.79) & 1.49 (1.39 to 1.60$)$ & 5557 (16.48) & $2530(21.24)$ & $1.54(1.44$ to 1.65$)$ \\
\hline $25-42$ & 751 (4.61) & $963(7.49)$ & 1.91 (1.72 to 2.14$)$ & $1401(4.15)$ & $1090(9.15)$ & 2.66 (2.42 to 2.93 ) \\
\hline$\geq 42$ & $201(1.23)$ & $298(2.32)$ & 2.15 (1.78 to 2.61$)$ & $432(1.28)$ & $441(3.70)$ & 3.26 (2.81 to 3.77 ) \\
\hline Unknown & $1666(10.23)$ & $1089(8.47)$ & 1.15 (1.05 to 1.25$)$ & 7641 (22.66) & 2225 (18.68) & 1.16 (1.09 to 1.24$)$ \\
\hline \multicolumn{7}{|l|}{ Body mass index: } \\
\hline$<20$ & $379(2.33)$ & $123(0.96)$ & 0.61 (0.49 to 0.76$)$ & 1209 (3.59) & $192(1.61)$ & $0.67(0.57$ to 0.79$)$ \\
\hline $20-24.9$ & $3990(24.51)$ & $1963(15.27)$ & 1 & 9909 (29.39) & $2262(18.99)$ & 1 \\
\hline $25-29.9$ & $6358(39.05)$ & 4955 (38.54) & 1.55 (1.45 to 1.66$)$ & $10265(30.44)$ & $4214(35.38)$ & $1.76(1.66$ to 1.87$)$ \\
\hline$\geq 30$ & $3702(22.74)$ & $4560(35.46)$ & 2.19 (2.04 to 2.36$)$ & $3710(11.00)$ & $2616(21.96)$ & 2.71 (2.52 to 2.90$)$ \\
\hline Unknown & $1851(11.37)$ & $1257(9.78)$ & $1.56(1.42$ to 1.71$)$ & 8627 (25.58) & $2626(22.05)$ & 1.49 (1.39 to 1.59$)$ \\
\hline \multicolumn{7}{|l|}{ Medical conditions: } \\
\hline $\begin{array}{l}\text { Ischaemic heart } \\
\text { disease }\end{array}$ & $3670(22.54)$ & 3289 (25.58) & 1.19 (1.12 to 1.26$)$ & 3046 (9.03) & $1634(13.72)$ & 1.54 (1.43 to 1.66$)$ \\
\hline Hyperlipidaemia & $3391(20.83)$ & $3305(25.70)$ & 1.14 (1.08 to 1.21$)$ & 2537 (7.52) & $1274(10.70)$ & 1.29 (1.20 to 1.39$)$ \\
\hline Renal failure & $338(2.08)$ & $727(5.65)$ & 2.32 (2.03 to 2.66 ) & $129(0.38)$ & $220(1.85)$ & 3.78 (3.00 to 4.76$)$ \\
\hline Heart failure & $808(4.96)$ & $1348(10.48)$ & 2.32 (2.11 to 2.56$)$ & $614(1.82)$ & $794(6.67)$ & 4.06 (3.60 to 4.58$)$ \\
\hline
\end{tabular}

*Adjusted for sex, age, calendar year, and visits to general practitioner.

$\dagger 1$ unit=10 $\mathrm{ml}$ of pure ethanol $(8 \mathrm{~g}$ of alcohol). 


\begin{tabular}{|c|c|c|c|c|c|c|c|}
\hline \multirow[b]{2}{*}{$\begin{array}{l}\text { Use of } \\
\text { antihypertensives }\end{array}$} & \multicolumn{3}{|c|}{ Hypertension } & \multicolumn{3}{|c|}{ No hypertension } & \multirow[b]{2}{*}{$\begin{array}{c}\mathbf{P} \text { for } \\
\text { interaction }\end{array}$} \\
\hline & $\begin{array}{c}\text { No }(\%) \text { of } \\
\text { controls }(n=16 \\
280)\end{array}$ & $\begin{array}{c}\text { No }(\%) \text { of cases } \\
\quad(n=12858)\end{array}$ & $\begin{array}{l}\text { Adjusted relative } \\
\text { risk }^{\star}(95 \% \mathrm{Cl})\end{array}$ & $\begin{array}{c}\text { No }(\%) \text { of } \\
\text { controls }(n=33 \\
720)\end{array}$ & $\begin{array}{c}\text { No }(\%) \text { of cases } \\
(n=11910)\end{array}$ & $\begin{array}{l}\text { Adjusted relative } \\
\text { risk }^{\star}(95 \% \mathrm{Cl})\end{array}$ & \\
\hline \multicolumn{8}{|l|}{ Diuretics: } \\
\hline Never & 6076 (37.32) & 2761 (21.47) & 1 & $30161(89.45)$ & 9445 (79.30) & 1 & \multirow[t]{4}{*}{0.03} \\
\hline Current (<31 days) & $6854(42.10)$ & $8159(63.45)$ & 2.36 (2.21 to 2.52$)$ & $1728(5.12)$ & $1762(14.79)$ & 3.01 (2.72 to 3.33 ) & \\
\hline Recent (31-365 days) & $1001(6.15)$ & $806(6.27)$ & $1.57(1.40$ to 1.76$)$ & $461(1.37)$ & $244(2.05)$ & 1.65 (1.38 to 1.97$)$ & \\
\hline Past (>365 days) & $2349(14.43)$ & $1132(8.80)$ & 0.98 (0.90 to 1.08$)$ & $1370(4.06)$ & $459(3.85)$ & 1.05 (0.93 to 1.18$)$ & \\
\hline \multicolumn{8}{|l|}{$\beta$ blockers: } \\
\hline Never & 8089 (49.69) & $5079(39.50)$ & 1 & $29711(88.11)$ & $9933(83.40)$ & 1 & \multirow[t]{4}{*}{0.04} \\
\hline Current (<31 days) & $4749(29.17)$ & 4967 (38.63) & 1.48 (1.40 to 1.57$)$ & $1620(4.80)$ & $962(8.08)$ & 1.16 (1.04 to 1.29$)$ & \\
\hline Recent (31-365 days) & $671(4.12)$ & $625(4.86)$ & $1.20(1.06$ to 1.36$)$ & $405(1.20)$ & $204(1.71)$ & $1.12(0.93$ to 1.36$)$ & \\
\hline Past ( $>365$ days) & $2771(17.02)$ & $2187(17.01)$ & $1.03(0.96$ to 1.11$)$ & $1984(5.88)$ & $811(6.81)$ & $0.97(0.88$ to 1.06$)$ & \\
\hline \multicolumn{8}{|l|}{$\begin{array}{l}\text { Calcium channel } \\
\text { blockers: }\end{array}$} \\
\hline Never & $9127(56.06)$ & $6685(51.99)$ & 1 & 31768 (94.21) & 10951 (91.95) & 1 & \multirow[t]{4}{*}{0.17} \\
\hline Current (<31 days) & $4603(28.27)$ & $3388(26.35)$ & $0.87(0.82$ to 0.93$)$ & $997(2.96)$ & $447(3.75)$ & $0.84(0.73$ to 0.97$)$ & \\
\hline Recent (31-365 days) & $651(4.00)$ & $670(5.21)$ & $1.03(0.91$ to 1.17$)$ & $194(0.58)$ & $95(0.80)$ & $0.72(0.55$ to 0.96$)$ & \\
\hline Past (>365 days) & $1899(11.66)$ & $2115(16.45)$ & $1.13(1.04$ to 1.23$)$ & $761(2.26)$ & $417(3.50)$ & $0.96(0.82$ to 1.11$)$ & \\
\hline \multicolumn{8}{|l|}{$\begin{array}{l}\text { Angiotensin converting } \\
\text { enzyme inhibitors: }\end{array}$} \\
\hline Never & $9238(56.74)$ & $5630(43.79)$ & 1 & $32103(95.20)$ & $10412(87.42)$ & 1 & \multirow[t]{4}{*}{0.04} \\
\hline Current (<31 days) & $4733(29.07)$ & $4818(37.47)$ & 1.24 (1.17 to 1.32$)$ & $1136(3.37)$ & $1085(9.11)$ & $1.37(1.21$ to 1.54$)$ & \\
\hline Recent (31-365 days) & $598(3.67)$ & $709(5.51)$ & $1.32(1.16$ to 1.50$)$ & $162(0.48)$ & $144(1.21)$ & 1.36 (1.05 to 1.77$)$ & \\
\hline Past (>365 days) & $1711(10.51)$ & $1701(13.23)$ & $1.08(0.99$ to 1.19$)$ & $319(0.95)$ & $269(2.26)$ & $1.11(0.90$ to 1.38$)$ & \\
\hline \multicolumn{8}{|l|}{ Losartan: } \\
\hline Never & 15551 (95.52) & $12141(94.42)$ & 1 & 33596 (99.63) & 11797 (99.05) & 1 & \multirow[t]{4}{*}{0.20} \\
\hline Current (<31 days) & $482(2.96)$ & 397 (3.09) & $0.81(0.70$ to 0.94$)$ & $92(0.27)$ & $72(0.60)$ & 0.90 (0.62 to 1.30$)$ & \\
\hline Recent (31-365 days) & $77(0.47)$ & $83(0.65)$ & $0.96(0.68$ to 1.35$)$ & $16(0.05)$ & $11(0.09)$ & $0.51(0.21$ to 1.25$)$ & \\
\hline Past ( $>365$ days) & $170(1.04)$ & $237(1.84)$ & 1.10 (0.89 to 1.37$)$ & $16(0.05)$ & $30(0.25)$ & $1.74(0.88$ to 3.43$)$ & \\
\hline \multicolumn{8}{|l|}{$\begin{array}{l}\text { Non-losartan } \\
\text { angiotensin II receptor } \\
\text { blockers: }\end{array}$} \\
\hline Never & $15073(92.59)$ & $11270(87.65)$ & 1 & 33581 (99.59) & $11728(98.47)$ & 1 & \multirow[t]{4}{*}{0.72} \\
\hline Current (<31 days) & $895(5.50)$ & $1223(9.51)$ & $1.29(1.16$ to 1.43$)$ & $108(0.32)$ & $145(1.22)$ & $1.40(1.04$ to 1.88$)$ & \\
\hline Recent (31-365 days) & $134(0.82)$ & $150(1.17)$ & $1.05(0.81$ to 1.35$)$ & $15(0.04)$ & $16(0.13)$ & $1.24(0.55$ to 2.80$)$ & \\
\hline Past ( $>365$ days) & $178(1.09)$ & $215(1.67)$ & $1.13(0.91$ to 1.41$)$ & $16(0.05)$ & $21(0.18)$ & 1.20 (0.56 to 2.58$)$ & \\
\hline
\end{tabular}

*Adjusted for sex, age, calendar year, number of visits to a general practitioner, body mass index, alcohol intake, ischaemic heart disease, hyperlipidaemia, diabetes, chronic renal failure and heart failure, and simultaneously for the other antihypertensive drug classes. 
Table 3| Relative risk of gout associated with duration of use of antihypertensive drugs among current users, stratified by presence of hypertension

\begin{tabular}{|c|c|c|c|c|c|c|}
\hline \multirow[b]{2}{*}{$\begin{array}{l}\text { Duration of } \\
\text { antihypertensive use }\end{array}$} & \multicolumn{3}{|c|}{ Hypertension } & \multicolumn{3}{|c|}{ No hypertension } \\
\hline & $\begin{array}{l}\text { No }(\%) \text { of controls } \\
\quad(n=16280)\end{array}$ & $\begin{array}{c}\text { No }(\%) \text { of cases } \\
(n=12858)\end{array}$ & $\begin{array}{c}\text { Adjusted relative risk } \\
(95 \% \mathrm{Cl})\end{array}$ & $\begin{array}{c}\text { No }(\%) \text { of } \\
\text { controls }(n=33 \\
720)\end{array}$ & $\begin{array}{c}\text { No }(\%) \text { of cases } \\
(n=11910)\end{array}$ & $\begin{array}{c}\text { Adjusted relative risk* } \\
(95 \% \mathrm{Cl})\end{array}$ \\
\hline \multicolumn{7}{|l|}{ Diuretics: } \\
\hline$<1$ year & $1751(10.76)$ & 1566 (12.18) & 1.79 (1.63 to 1.96$)$ & $570(1.69)$ & $436(3.66)$ & 2.26 (1.94 to 2.62$)$ \\
\hline $1-1.9$ years & $1160(7.13)$ & $1295(10.07)$ & 2.27 (2.05 to 2.51 ) & $309(0.92)$ & $290(2.43)$ & 2.77 (2.28 to 3.35$)$ \\
\hline$\geq 2$ years & $3943(24.22)$ & $5298(41.20)$ & 2.62 (2.44 to 2.82 ) & $849(2.52)$ & $1036(8.70)$ & 3.63 (3.20 to 4.12 ) \\
\hline$P$ for trend & & & $<0.001$ & & & $<0.001$ \\
\hline \multicolumn{7}{|l|}{$\beta$ blockers: } \\
\hline$<1$ year & $933(5.73)$ & $861(6.70)$ & 1.36 (1.21 to 1.51$)$ & $503(1.49)$ & $262(2.20)$ & $1.10(0.93$ to 1.32$)$ \\
\hline $1-1.9$ years & $691(4.24)$ & $732(5.69)$ & 1.52 (1.35 to 1.72$)$ & $264(0.78)$ & $188(1.58)$ & 1.23 (0.98 to 1.54$)$ \\
\hline$\geq 2$ years & $3125(19.20)$ & $3374(26.24)$ & 1.47 (1.38 to 1.57$)$ & $853(2.53)$ & $512(4.30)$ & $1.18(1.03$ to 1.35$)$ \\
\hline$P$ for trend & & & 0.15 & & & 0.24 \\
\hline \multicolumn{7}{|l|}{$\begin{array}{l}\text { Calcium channel } \\
\text { blockers: }\end{array}$} \\
\hline$<1$ year & $1180(7.25)$ & $1004(7.81)$ & $1.04(0.94$ to 1.15$)$ & $269(0.80)$ & $116(0.97)$ & 0.81 (0.63 to 1.04$)$ \\
\hline $1-1.9$ years & $737(4.53)$ & $549(4.27)$ & $0.89(0.78$ to 1.00$)$ & $156(0.46)$ & $79(0.66)$ & 0.92 (0.68 to 1.27 ) \\
\hline$\geq 2$ years & $2686(16.50)$ & $1835(14.27)$ & 0.77 (0.71 to 0.83 ) & $572(1.70)$ & $252(2.12)$ & 0.80 (0.67 to 0.96$)$ \\
\hline P for trend & & & $<0.001$ & & & 0.87 \\
\hline \multicolumn{7}{|l|}{$\begin{array}{l}\text { Angiotensin converting } \\
\text { enzyme inhibitors: }\end{array}$} \\
\hline$<1$ year & $1198(7.36)$ & $1058(8.23)$ & 1.09 (0.99 to 1.20$)$ & $360(1.07)$ & $276(2.32)$ & 1.27 (1.05 to 1.53$)$ \\
\hline $1-1.9$ years & 801 (4.92) & 719 (5.59) & 1.08 (0.96 to 1.22$)$ & $219(0.65)$ & $190(1.60)$ & 1.38 (1.09 to 1.74$)$ \\
\hline$\geq 2$ years & 2734 (16.79) & $3041(23.65)$ & 1.32 (1.23 to 1.42$)$ & $557(1.65)$ & $619(5.20)$ & 1.40 (1.20 to 1.63$)$ \\
\hline$P$ for trend & & & $<0.001$ & & & 0.71 \\
\hline \multicolumn{7}{|l|}{ Losartan: } \\
\hline$<1$ year & $127(0.78)$ & $117(0.91)$ & 0.97 (0.74 to 1.27$)$ & $25(0.07)$ & $15(0.13)$ & $0.71(0.35$ to 1.45$)$ \\
\hline $1-1.9$ years & $96(0.59)$ & $80(0.62)$ & 0.86 (0.62 to 1.18$)$ & $22(0.07)$ & $14(0.12)$ & 1.04 (0.49 to 2.22 ) \\
\hline$\geq 2$ years & $259(1.59)$ & $200(1.56)$ & $0.70(0.57$ to 0.86$)$ & $45(0.13)$ & $43(0.36)$ & 0.84 (0.52 to 1.37$)$ \\
\hline$P$ for trend & & & 0.02 & & & 0.185 \\
\hline
\end{tabular}

Non-losartan

angiotensin II receptor

blockers:

\begin{tabular}{lllcllc}
\hline$<1$ year & $316(1.94)$ & $381(2.96)$ & $1.20(1.02$ to 1.42$)$ & $46(0.14)$ & $66(0.55)$ & $1.54(1.00$ to 2.35$)$ \\
\hline $1-1.9$ years & $203(1.25)$ & $275(2.14)$ & $1.30(1.06$ to 1.59$)$ & $26(0.08)$ & $33(0.28)$ & $1.30(0.73$ to 2.32$)$ \\
\hline$\geq 2$ years & $376(2.31)$ & $567(4.41)$ & $1.33(1.14$ to 1.54$)$ & $36(0.11)$ & $46(0.39)$ & $1.12(0.68$ to 1.86$)$ \\
\hline$P$ for trend & & 0.67 & & 0.12
\end{tabular}

*Adjusted for sex, age, calendar year, number of visits to general practitioner, body mass index, alcohol intake, ischaemic heart disease, hyperlipidaemia, diabetes, chronic renal failure, heart failure, and simultaneously for the other antihypertensive drug classes. 
Table 4 | Relative risk of gout associated with daily dose of antihypertensive agents among current users, stratified by presence of hypertension

\begin{tabular}{|c|c|c|c|c|c|c|}
\hline \multirow[b]{2}{*}{ Daily dose } & \multicolumn{3}{|c|}{ Hypertension } & \multicolumn{3}{|c|}{ No hypertension } \\
\hline & $\begin{array}{c}\text { No }(\%) \text { of } \\
\text { controls }(n=16 \\
280)\end{array}$ & $\begin{array}{c}\text { No }(\%) \text { of } \\
\text { cases }(n=12 \\
858)\end{array}$ & $\begin{array}{l}\text { Adjusted relative } \\
\text { risk* }^{*}(95 \% \mathrm{Cl})\end{array}$ & $\begin{array}{c}\text { No }(\%) \text { of controls } \\
(n=33720)\end{array}$ & $\begin{array}{c}\text { No }(\%) \text { of cases }(n=11 \\
910)\end{array}$ & $\begin{array}{c}\text { Adjusted relative risk* } \\
(95 \% \mathrm{Cl})\end{array}$ \\
\hline \multicolumn{7}{|l|}{ Diuretics: } \\
\hline $\begin{array}{l}\text { Low or medium } \\
\text { dose }\end{array}$ & $5630(34.58)$ & $6320(49.15)$ & 2.24 (2.09 to 2.39 ) & $1361(4.04)$ & 1249 (10.49) & 2.72 (2.44 to 3.03 ) \\
\hline High dose & $579(3.56)$ & $971(7.55)$ & 2.99 (2.63 to 3.40$)$ & $263(0.78)$ & $419(3.52)$ & 4.16 (3.45 to 5.02$)$ \\
\hline Unknown & $645(3.96)$ & $868(6.75)$ & 2.76 (2.43 to 3.12 ) & $104(0.31)$ & $94(0.79)$ & 3.60 (2.63 to 4.92$)$ \\
\hline \multicolumn{7}{|l|}{$\beta$ blockers: } \\
\hline $\begin{array}{l}\text { Low or medium } \\
\text { dose }\end{array}$ & $3234(19.86)$ & $3156(24.55)$ & 1.39 (1.30 to 1.49$)$ & $1258(3.73)$ & $697(5.85)$ & 1.15 (1.02 to 1.29$)$ \\
\hline High dose & $1377(8.46)$ & $1677(13.04)$ & 1.59 (1.46 to 1.74$)$ & $319(0.95)$ & 237 (1.99) & 1.14 (0.94 to 1.39$)$ \\
\hline Unknown & $138(0.85)$ & $134(1.04)$ & 1.63 (1.25 to 2.13 ) & $43(0.13)$ & $28(0.24)$ & 1.69 (0.99 to 2.90$)$ \\
\hline \multicolumn{7}{|l|}{$\begin{array}{l}\text { Calcium channel } \\
\text { blockers: }\end{array}$} \\
\hline $\begin{array}{l}\text { Low or medium } \\
\text { dose }\end{array}$ & 2298 (14.12) & $1757(13.66)$ & 0.90 (0.84 to 0.98 ) & $626(1.86)$ & $272(2.28)$ & 0.83 (0.70 to 0.99$)$ \\
\hline High dose & 2271 (13.95) & $1596(12.41)$ & 0.80 (0.74 to 0.87$)$ & $359(1.06)$ & $170(1.43)$ & 0.84 (0.67 to 1.04$)$ \\
\hline Unknown & $34(0.21)$ & $35(0.27)$ & 1.80 (1.07 to 3.04$)$ & $12(0.04)$ & $5(0.04)$ & 1.26 (0.36 to 4.38$)$ \\
\hline \multicolumn{7}{|c|}{$\begin{array}{l}\text { Angiotensin } \\
\text { converting enzyme } \\
\text { inhibitors: }\end{array}$} \\
\hline $\begin{array}{l}\text { Low or medium } \\
\text { dose }\end{array}$ & $1998(12.27)$ & $1848(14.37)$ & 1.23 (1.14 to 1.33 ) & $657(1.95)$ & $538(4.52)$ & $1.33(1.15$ to 1.54$)$ \\
\hline High dose & 2665 (16.37) & $2914(22.66)$ & 1.23 (1.15 to 1.33$)$ & $465(1.38)$ & $532(4.47)$ & 1.39 (1.18 to 1.63$)$ \\
\hline Unknown & $70(0.43)$ & $56(0.44)$ & 0.96 (0.65 to 1.41$)$ & $14(0.04)$ & $15(0.13)$ & 1.84 (0.81 to 4.21$)$ \\
\hline \multicolumn{7}{|l|}{ Losartan: } \\
\hline $\begin{array}{l}\text { Low or medium } \\
\text { dose }\end{array}$ & $287(1.76)$ & $245(1.91)$ & 0.88 (0.73 to 1.06$)$ & $77(0.23)$ & $61(0.51)$ & 0.93 (0.63 to 1.39$)$ \\
\hline High dose & $190(1.17)$ & $149(1.16)$ & 0.66 (0.52 to 0.84$)$ & $15(0.04)$ & $10(0.08)$ & $0.52(0.22$ to 1.26$)$ \\
\hline Unknown & $5(0.03)$ & $3(0.02)$ & 0.66 (0.15 to 2.89 ) & $0(0.00)$ & $1(0.01)$ & - \\
\hline \multicolumn{7}{|l|}{$\begin{array}{l}\text { Non-losartan } \\
\text { angiotensin II } \\
\text { receptor blockers: }\end{array}$} \\
\hline $\begin{array}{l}\text { Low or medium } \\
\text { dose }\end{array}$ & $582(3.57)$ & $712(5.54)$ & 1.20 (1.06 to 1.36$)$ & $89(0.26)$ & $0.94)$ & 1.24 (0.90 to 1.72$)$ \\
\hline High dose & $298(1.83)$ & $486(3.78)$ & 1.40 (1.19 to 1.65$)$ & $18(0.05)$ & 0.27) & 1.89 (0.98 to 3.61$)$ \\
\hline Unknown & $15(0.09)$ & $25(0.19)$ & 1.14 (0.58 to 2.25 ) & $1(0.01)$ & .01) & 0.85 (0.03 to 24.19 ) \\
\hline
\end{tabular}

*Adjusted for sex, age, calendar year, number of visits to general practitioner, body mass index, alcohol intake, ischaemic heart disease, hyperlipidaemia, diabetes, chronic renal failure, heart failure, and simultaneously for the other antihypertensive drug classes. 